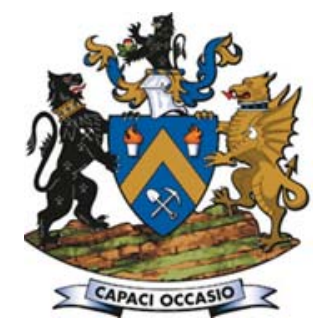

\title{
Prevention of spontaneous combustion in coal drifts using a lining material: a case study of the Tuncbilek Omerler underground mine, Turkey
}

\author{
by M.V. Ozdogan, G. Turan, D. Karakus, A.H. Onur G. Konak, \\ and E. Yalcin
}

\section{Synopsis}

The spontaneous combustion of coal in underground mines is a vital subject for miners. Every year, many coal fire incidents are caused by spontaneous combustion.

In this study, a lining material for coating the coal surface to prevent coal fires was designed in laboratory conditions. Three kinds of gypsum as well as plaster, satin plaster, moulding plaster, hydrated lime, cement, and fly ash were used to prepare different types of mixtures.

Sixteen different mixtures were prepared and tested. Only plaster plus water and cement plus fly ash plus water gave satisfactory results in the laboratory tests, and these mixtures were then applied on a small scale in an underground coal mine. Observations showed that plaster reacted with pyrite, increasing the porosity of the lining material upon exposure to water, which is ubiquitous in underground mines. However, a 7-8 mm thick application of the cement plus fly ash plus water mixture proved impermeable to air and maintained its structure in underground mine conditions. The cement and fly ash mixture was then applied to some hazardous areas on a larger scale. When the investigations were completed, the lining material was applied in new development drifts that had been driven into the coal at the Omerler underground mine.

Keywords

spontaneous combustion, coal fire, lining material, coating.

\section{Introduction}

Spontaneous combustion is an oxidation reaction that occurs without an external heat source (Philips, Uludağ, and Chabedi, 2011). All coals have the potential to combust spontaneously, thereby constituting a potential coal fire risk caused by the auto-oxidation of coal. Spontaneous combustion has been one of the major hazards in underground coal mines for very many years. It causes safety problems and economic losses as a result of inaccessible underground areas. Many methods exist for the detection, prevention, and management of spontaneous combustion in surface mining operations, but in underground mines most of the methods developed for detecting and preventing fires have been unsuccessful. Although the ignition of coal can be detected at the coal surface, the combustion of coal occurs quickly, and it may often be too late to take precautions before a fire begins. So, unexpected mine accidents may take place, and many miners may lose their lives.

Underground coal fires occur in many countries worldwide. One of the most recent significant mine accidents caused by coal fire happened in the Soma underground coal mine in Turkey on 13 May 2014. Unfortunately, 301 miners died in that accident.

Coal fires require three basic elements: oxygen, heat, and fuel. If one of these elements is removed from the environment or contact between them is interrupted, the fire mechanism tends to be suppressed. In coal mines, coal is the main source of fuel, oxygen is needed for the workers, and heat is generated by the exothermic reaction of coal and oxygen, so none of these elements can be removed from the environment. However, the contact between coal and oxygen can be obstructed.

Several theoretical and experimental studies have been carried out on the theory, susceptibility, and detection of spontaneous coal combustion (Handa et al., 1985; Sarac and Soyturk, 1992; Grewer, 1994; Wang, Dlugogorski, and Kennedy, 1999; Kaymakçı and Didari, 2000; Guřanová, 2008; Zubíček, 2008; Zeng-hua et al., 2009; Li, Beamish, and Jiang, 2009; Singh, 2013; Liang and Wang, 2017). However, fewer studies exist on preventing the spontaneous combustion of coal, and most of the prevention methods are based on chemical agents. Goodson $\mathbb{Q}$ Associates Inc. has developed a new cellular (foam-containing) grout fire control technology called Thermocell. The basic grout is composed of sand, cement, and water and requires a high proportion of fly ash (a byproduct of coal combustion), to which a quantity of air-entraining foam is added (much like shaving cream) (Colaizzi, 2004).Tibbs et al. (2013) suggest a 'thin spray-on liner' for replacing steel mesh and they claim that this polymer-based coating material is an effective fire retardant.

\footnotetext{
* Department of Mining Engineering, Dokuz Eylul University, Izmir, Turkey.

(C) The Southern African Institute of Mining and Metallurgy, 2018. ISSN 2225-6253. Paper received Apr. 2017; revised paper received Oct. 2017.
} 


\section{Prevention of spontaneous combustion in coal drifts using a lining material}

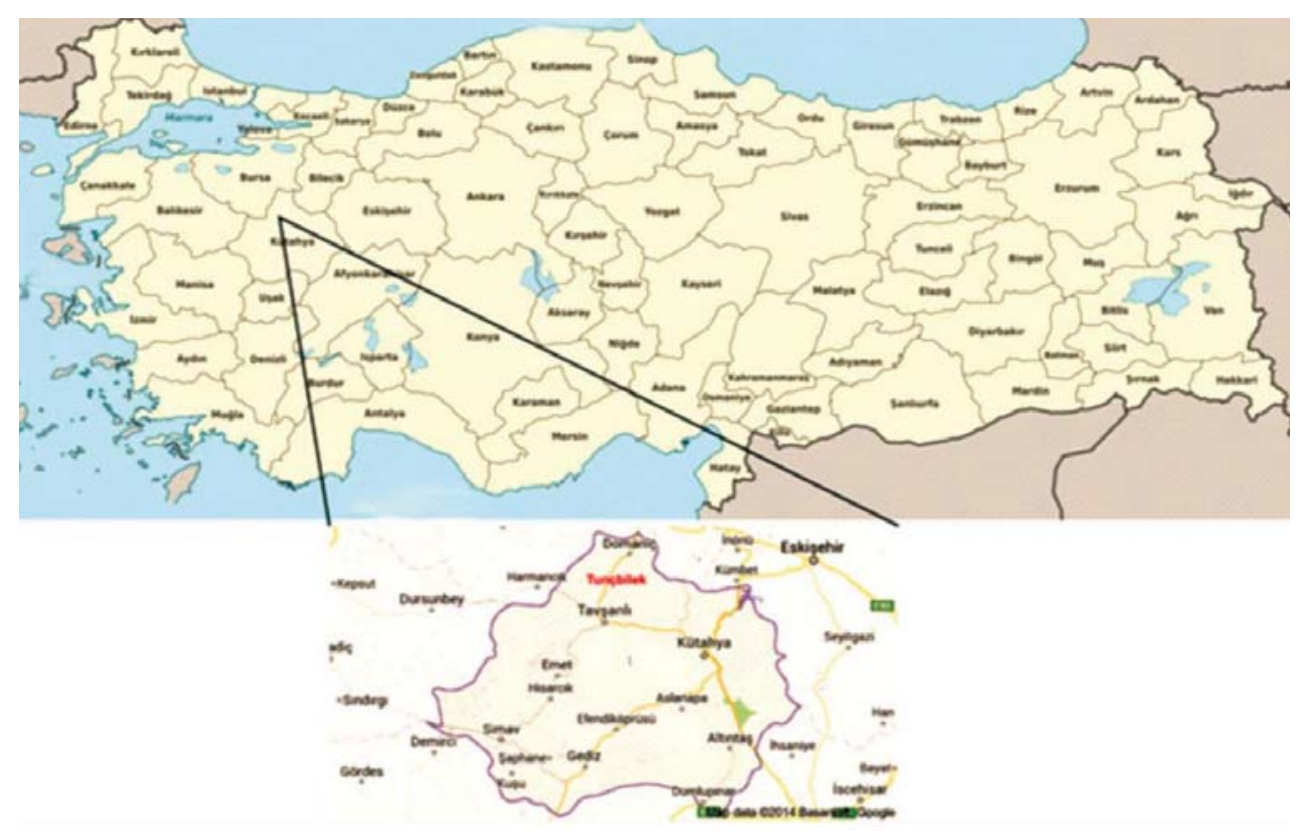

Figure 1-Location of Tuncbilek lignite district

Also, Li et al. (2016) reported the potential of a thin spray-on liner for controlling spontaneous combustion and various gas emissions. Wang et al. (2014) studied some chemical inhibitors to prevent the spontaneous combustion of coal due to its structure.

Many other commercial chemical agents have been used for coating the coal surface to prevent air contact, but their cost is quite high. Therefore, a coating application with chemical agents is generally used only for locations that have a high combustion risk. In this research, a cheap, airtight coating material was developed to prevent the contact between coal and oxygen.

\section{Study area}

The Tuncbilek lignite district is located in the north-east Aegean region of Turkey and is about $60 \mathrm{~km}$ away from Kutahya. The site location map is given in Figure 1. Turkish Coal Enterprise (TKI) is the owner of the lignite licences in the region and accounts for $7.5 \%$ of all Turkish lignite production in this licence area. According to statistics obtained from TKI for $2014,80 \%$ of lignite production came from open pits, whereas the remaining $20 \%$ was mined from an underground mine in the Omerler district (http://www.gli.gov.tr/faaliyet.html).

The Omerler underground coal mine was faced with fire problems in the years between 2009 and 2011. The development galleries, which were driven into the coal seam, became inaccessible because of the frequent ignition of coal. This caused serious economic losses and threatened the lives of workers. Chemical agents had been used for coating the coal surface, but only some risky areas were coated due to the high cost of lining material. This restricted application was not successful in preventing fires in the mine.

The first serious coal fire occurred on 8 November 2009 in $185 \mathrm{~m}$ of the tailgate of panel B2. The concentration of $\mathrm{CO}$ was measured at $200 \mathrm{ppm}$ in that part of the tailgate. The CO level reached $1000 \mathrm{ppm}$ in a very short time, and smoke was observed in the drift. Finally, open flame occurred in the tailgate, and the drift was closed with a fire dam. The second coal fire occurred on 30 May 2010 between 510 and $525 \mathrm{~m}$ of the bottom gate of panel B2. A CO concentration of $284 \mathrm{ppm}$ was detected initially and reached 400 ppm within one hour. It then increased to $1000 \mathrm{ppm}$ in a short period of time, and smoke was observed. After open flame was seen at the bottom gate, the drift was also closed with a fire dam. The third coal fire occurred on 22 December in haulage road K2, and the haulage way was also closed with a fire dam. The locations of the fires and panels are provided in Figure 2.

In this study, some types of materials with the potential to be used as economical linings for coal surfaces were tested for their ability to prevent spontaneous combustion in the Omerler underground coal mine. First, laboratory studies were carried out to determine the proper mixture. Then, an in-situ study and an industrial-scale application were carried out at the Omerler mine

\section{Mechanism of spontaneous combustion}

The complete oxidation of carbon to carbon dioxide is an exothermic reaction that emits between 21 and $42 \mathrm{~kJ}$ per gram of coal, taking into account that coal is not composed of pure carbon (Grewer, 1994).

The chemical and heat balances involved in the lowtemperature oxidation of coal, spontaneous combustion, and final combustion are illustrated by a few fundamental process equations, demonstrating the exothermic nature of the reaction (Grewer, 1994):

$$
\begin{aligned}
& \mathrm{C}+\mathrm{O}_{2} \rightarrow \mathrm{CO}_{2}+393.52 \mathrm{~kJ} / \mathrm{mol} \\
& 2 \mathrm{C}+\mathrm{O}_{2} \rightarrow 2 \mathrm{CO}+170 \mathrm{~kJ} / \mathrm{mol} \\
& \left.2 \mathrm{H}_{2}+\mathrm{O}_{2} \mathrm{H}_{2} \mathrm{O}+241.83 \mathrm{~kJ} / \mathrm{mol}\right)
\end{aligned}
$$

Because of its structure, as the coal comes into contact with oxygen, it adsorbs the oxygen. At temperatures above $40^{\circ} \mathrm{C}$, the adsorption leads to an exothermic reaction and causes the ambient temperature to increase (Sarac and 


\section{Prevention of spontaneous combustion in coal drifts using a lining material}

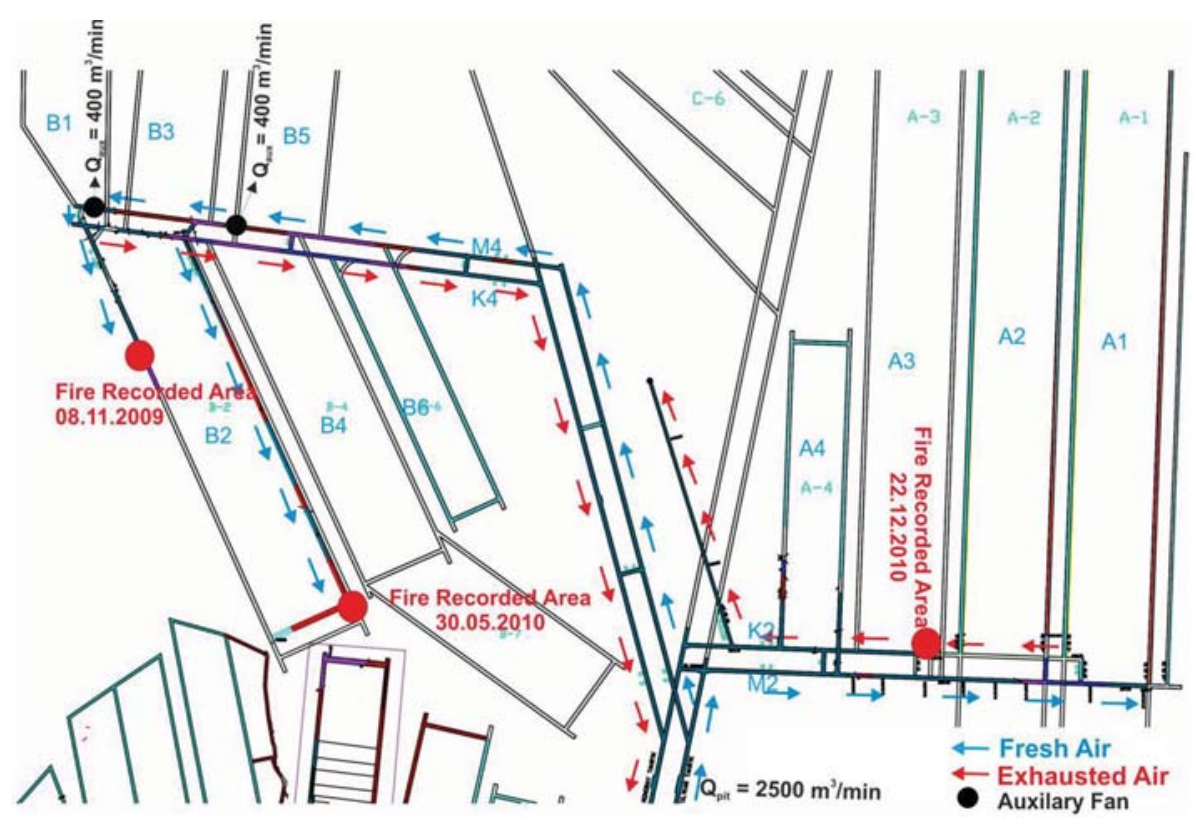

Figure 2-Location of fires in Omerler underground coal mine

\begin{tabular}{|l|l|l|}
\hline \multicolumn{3}{|l|}{ Table I Factors affecting spontaneous combustion (Singh, 2013) } \\
\hline Seam factors & Mining factors & Geological factors \\
\hline Rank & Mining methods & Seam thickness \\
Petrographic composition & Rate of advance & Seam gradient \\
Temperature & Pillar conditions & Caving characteristics \\
Available air & Roof condition & Faults/dykes \\
Particle size & Crushing & Coal outbursts \\
Moisture & Packing & Friability \\
Sulphur & Effect of timber & Depth of cover \\
Effect of previous oxidation & Leakage & \\
Physical properties & Multi-seam working & \\
Heating due to earth movement & Coal losses & \\
Bacteria & Main roads & \\
Other minerals & Worked-out areas & \\
& Stowing & \\
& Ventilating pressure & \\
& Humidity & \\
\hline
\end{tabular}

Soyturk, 1992). If this heat cannot be removed from the environment, the $\mathrm{CO}$ and $\mathrm{CO}_{2}$ concentrations increase at temperatures above $70^{\circ} \mathrm{C}$, and water vapour is given off at $125^{\circ} \mathrm{C}$. As the increasing temperature of the medium reaches the ignition temperature of coal, underground fires start (Sarac and Soyturk, 1992; Kural, 1998; Jones and Townend, 1949).

\section{Factors affecting spontaneous combustion}

A number of factors are significant when determining the risk of spontaneous combustion in coal. One of the earliest classifications of these factors was revealed by Davis and Reynolds (1928) (Philips, Uludağ, and Chabedi, 2011). The factors are grouped by chemical and physical properties. In order of importance, the chemical factors to be considered are the rank of the coal and the presence of pyrite, weathering, moisture, organic sulphur, chemical retardants (calcium chloride and sodium bicarbonate), ozone, and bacteria. The physical factors are particle size, moisture, oxygen supply, temperature, 'occluded' gases, and ventilation (Davis and Reynolds, 1928). Later, the Davis and Reynolds classification of factors was extended by various researchers. One of the latest classifications was mooted by Singh (2013), as shown in Table I.

The susceptibility of lignites in the Kutahya region to spontaneous combustion was examined by Oren and Sensogut (2010). The ignition temperatures, average heating rates, and liability indices of Kutahya region lignites vary in the ranges $141-188^{\circ} \mathrm{C}, 0.894-2.619^{\circ} \mathrm{C} / \mathrm{min}$, and $5.78-17.34$ min-1, respectively. Therefore, the lignites from the Kutahya region are in the 'medium-high' risk group (Oren and Sensogut, 2010) based on the classification developed by Feng (1973) and assuming an average heating rate between 110 and $220^{\circ} \mathrm{C}$. The proximate analysis and liability classification (Yildirim et al., 2006) for the study area are given in Table II. 


\section{Prevention of spontaneous combustion in coal drifts using a lining material}

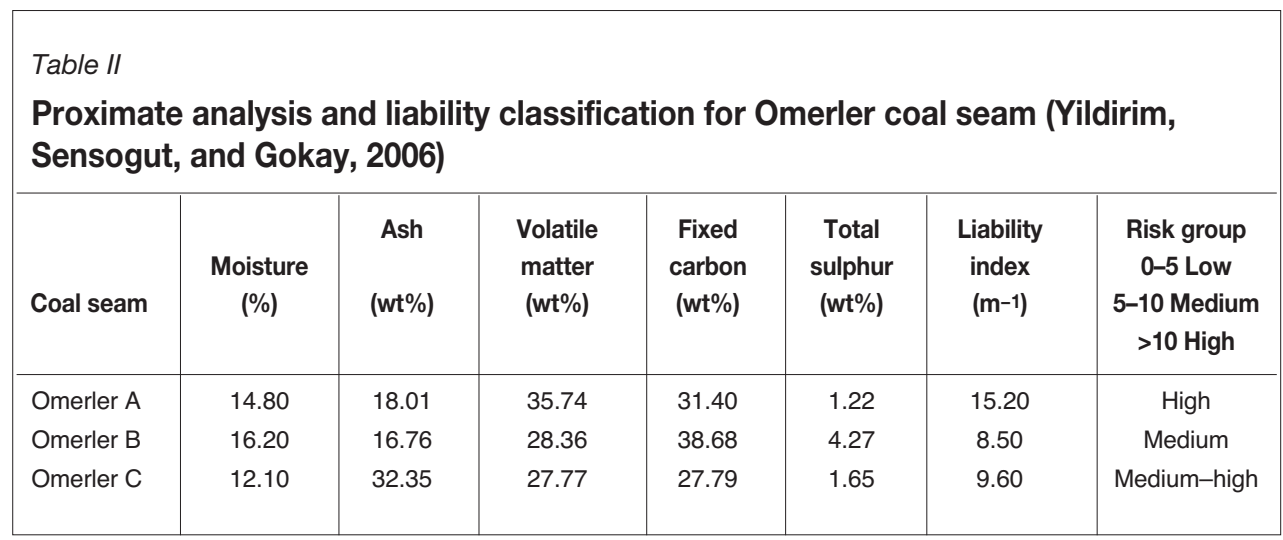

\section{Experimental investigations}

The lining material to be applied to prevent coal fires must be impermeable to air, inexpensive, resistant to water and heat, easy to obtain and apply, and have sufficient strength and a low rebound ratio during application. Also, it should not be harmful to human health and must be resistant to environmental effects. Although the main function of the lining material is not to support the roof load, it must be solid enough to form one unified piece across the applied surface. Otherwise, the lining may break or fall down and allow the reaction between coal and oxygen to proceed, resulting in the ignition of coal. For this purpose, three kinds of gypsum (plaster, satin plaster, and moulding plaster) as well as lime, cement, and fly ash were considered. Different mixtures of these materials were tested as a lining material in laboratory conditions. Then, the mixtures were subjected to laboratory tests to determine if they could meet the above-listed specifications. Subsequently, the mixtures were applied on a testing wall by means of a Mono pump to determine the applicability and rebound ratios of the mixtures. After all of tests were completed, the lining materials were applied at the Omerler underground coal mine on an industrial scale.

\section{Laboratory studies}

Sixteen mixtures were prepared in laboratory conditions. The contents and proportions of materials in the mixtures are shown in Table III.
The mixtures were prepared in cylindrical moulds to facilitate testing of their uniaxial compressive strength (UCS). They were cured under atmospheric conditions for 14 days, and the cured samples were tested in a compression machine to determine their UCS. The setting times of the mixtures were also determined. A short setting time would block the pump, whereas a long setting time would increase the rebound ratio of the mixture. The setting times of the mixtures were tested using a pin penetrating method: a pin was used to puncture samples repeatedly until it could not penetrate, and the corresponding time was recorded as the setting time for each mixture. A setting time of 15 minutes and less is considered to be risky.

One of the most important constraints for a lining material is air permeability. Only the samples that passed all of the other tests were subjected to the air permeability test. The samples were placed in a tube, which was then placed in a burette filled with water to an exact level (Figure 3).

The thickness ' $t$ ' that completely blocked air flow under certain air pressures was tested in the permeability test. Air pressure in the test device was obtained using a water column with a height of $10 \mathrm{~cm}$, which gave $100 \mathrm{~kg} / \mathrm{m}^{2}$ of air pressure $(980 \mathrm{~Pa})$. Specimens of different thicknesses were tested and those that did not cause any change in water level were accepted as airproof.

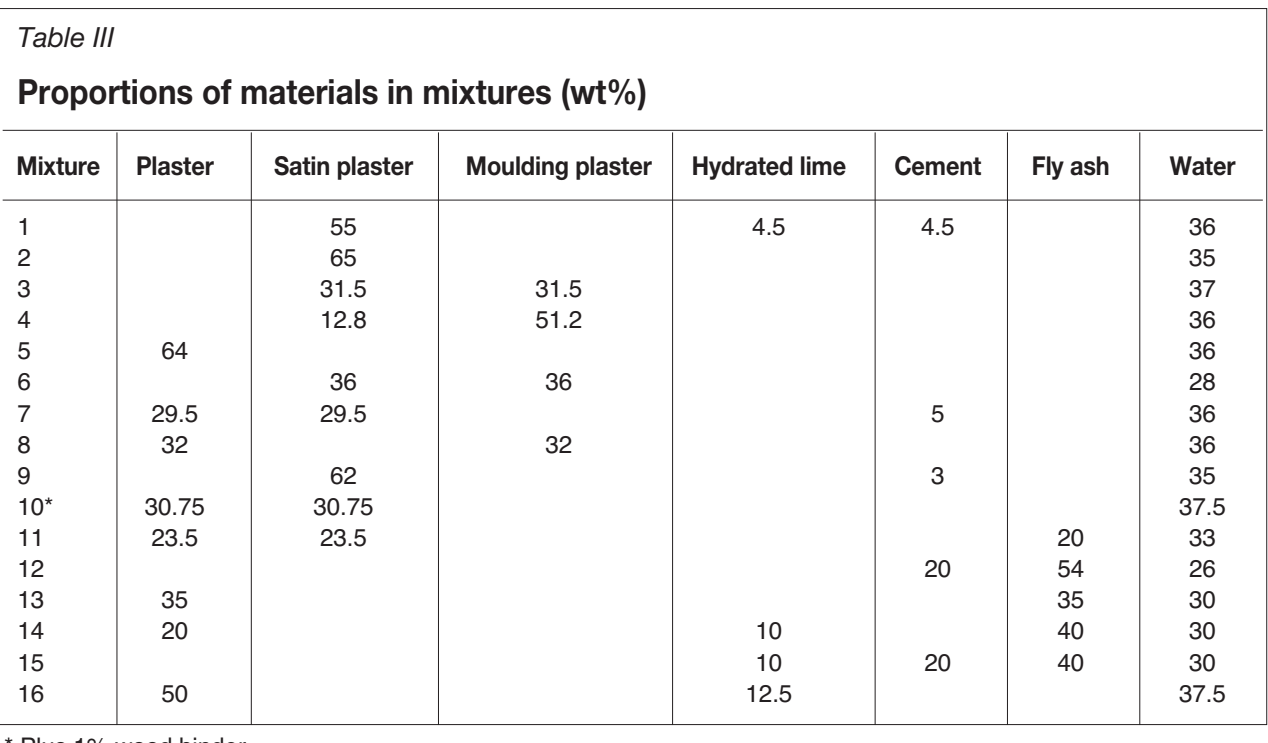

* Plus $1 \%$ wood binder 


\section{Prevention of spontaneous combustion in coal drifts using a lining material}

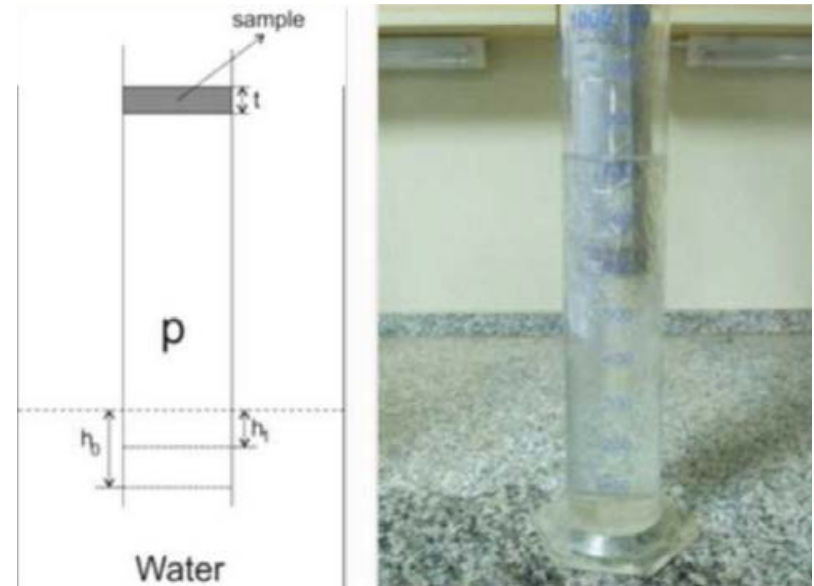

Figure 3-Test device for determining air permeability

\section{Studies on test wall}

After the laboratory tests, the mixtures were sprayed on a relatively large-scale, rough retaining wall using a Mono pump (2.5 kW, $380 \mathrm{~V})$ and compressor at 5 bar to conduct some observational tests (Figure 4).

The pumpability and rebound of the mixtures were evaluated by observation during the application studies on the test wall. These studies yielded a methodology for finding the best applicable thicknesses for the mixtures. After the spraying process, the coatings on the wall were watered every day to determine their water resistance.

\section{Results of experimental investigations}

The UCS, setting time, pumpability, rebound ratio, air permeability, and water resistance of the mixtures are given in Table IV.
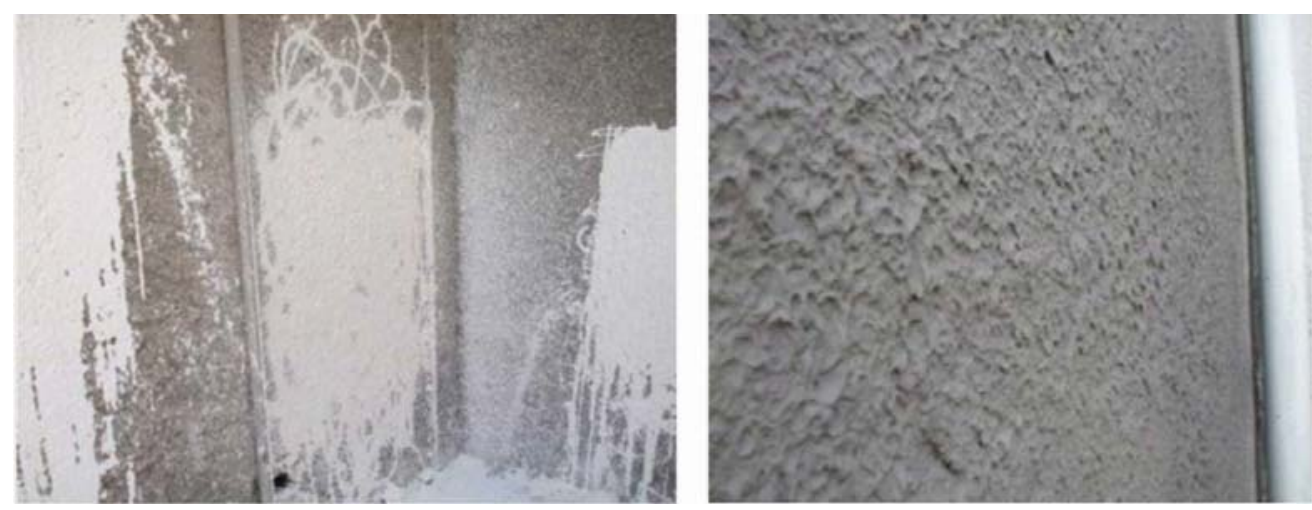

Figure 4-Mixtures sprayed on wall

Table IV

Results of experimental investigations

\begin{tabular}{|c|c|c|c|c|c|c|}
\hline Mixture no. & $\begin{array}{l}\text { Unit weight } \\
\left(\mathrm{kN} / \mathrm{m}^{3}\right)\end{array}$ & $\begin{array}{l}\text { UCS }^{*} \\
\text { (14 days) } \\
\text { (MPa) }\end{array}$ & $\begin{array}{l}\text { Setting time } \\
\text { (min) }\end{array}$ & $\begin{array}{l}\text { Resistance to water } \\
\text { (Empirical) }\end{array}$ & $\begin{array}{l}\text { Rebound } \\
\text { (Empirical) }\end{array}$ & Comment \\
\hline 1 & 10.10 & 2.95 & $>60$ & Washed & High & Low water resistance (failed) \\
\hline 2 & 11.18 & 3.76 & $>180$ & Unwashed & Low & Long setting time (failed) \\
\hline 3 & 11.18 & 3.61 & $>60$ & Unwashed & Low & Acceptable \\
\hline 4 & 11.67 & 8.52 & 80 & Washed & Low & Low water resistance (failed) \\
\hline 5 & 11.77 & 14.05 & 26 & Unwashed & Low & Acceptable \\
\hline 6 & 14.13 & 9.84 & 90 & Washed & Low & Low water resistance (failed) \\
\hline 7 & 11.48 & 8.95 & 75 & Washed & High & High rebound and low water resistance (failed) \\
\hline 8 & 11.87 & 11.71 & 20 & Unwashed & High & Acceptable \\
\hline 9 & 11.48 & 5.11 & $>60$ & Washed & High & Low water resistance (failed) \\
\hline 10 & 10.89 & 5.84 & $>60$ & Unwashed & Low & Highly fractured (failed) \\
\hline 11 & 11.77 & 9.07 & $>60$ & Washed & Low & Low water resistance (failed) \\
\hline 12 & 13.44 & 7.78 & $>60$ & Unwashed & Low & Acceptable \\
\hline 13 & 12.26 & 12.45 & 10 & Unwashed & Low & Short setting time (failed) \\
\hline 14 & 10.69 & 4.91 & 15 & Unwashed & Low & Acceptable \\
\hline 15 & 11.58 & 3.91 & 40 & Unwashed & High & High rebound (failed) \\
\hline 16 & 9.91 & 9.02 & 20 & Unwashed & High & High rebound (failed) \\
\hline
\end{tabular}

* UCS: Uniaxial compression strength over 14 days 


\section{Prevention of spontaneous combustion in coal drifts using a lining material}

The mixtures that passed all of the tests (mixtures 3, 5, 8, 12 , and 14) were subjected to the air permeability test. Only mixtures 5 and 12 tested as impermeable at a $5 \mathrm{~mm}$ thickness and were accepted as airproof.

\section{Site application}

After all of the laboratory tests and observations were completed, mixtures 5 and 12 were considered as suitable mixtures. The first small-scale test applications of mixture 5 (plaster plus water) and mixture 12 (cement plus fly ash plus water) were carried out at the Omerler underground coal mine in a small part of a drift that was opened in the coal (Figures $5 \mathrm{a}$ and $5 \mathrm{~b}$ ).

Both mixtures were applied successfully and both demonstrated strong adhesion to coal. After 10 days of observation, cracks and splitting were apparent in mixture 5 . The plaster $\left(\mathrm{CaSO}_{4}\right.$ plus $\left.0.5 \mathrm{H}_{2} \mathrm{O}\right)$ also interacted with pyrite in the coal to form $\mathrm{FeSO}_{4}$. This reaction occurred rapidly, and the $\mathrm{FeSO}_{4}$ was visible on the lining material as a yellow colour (Figure 6).

One piece of the lining material containing $\mathrm{FeSO}_{4}$ was taken from the test area and exposed to water. This lining material dissolved in water and became porous, which showed that the plaster and water mixture could not provide air tightness. So mixture 5 failed in underground conditions.

Mixture 12 was undisturbed and kept its original shape. During the two-month observation period, the cement plus fly ash and water mixture did not undergo any reaction. Subsequently, a second application was tested in the coal drift. The wedges between two supports were removed, mixture 12 was applied between the two support elements, and the wedges were replaced (Figure 7). Three coatings of the mixture were applied to increase the lining thickness to $7-8 \mathrm{~mm}$.
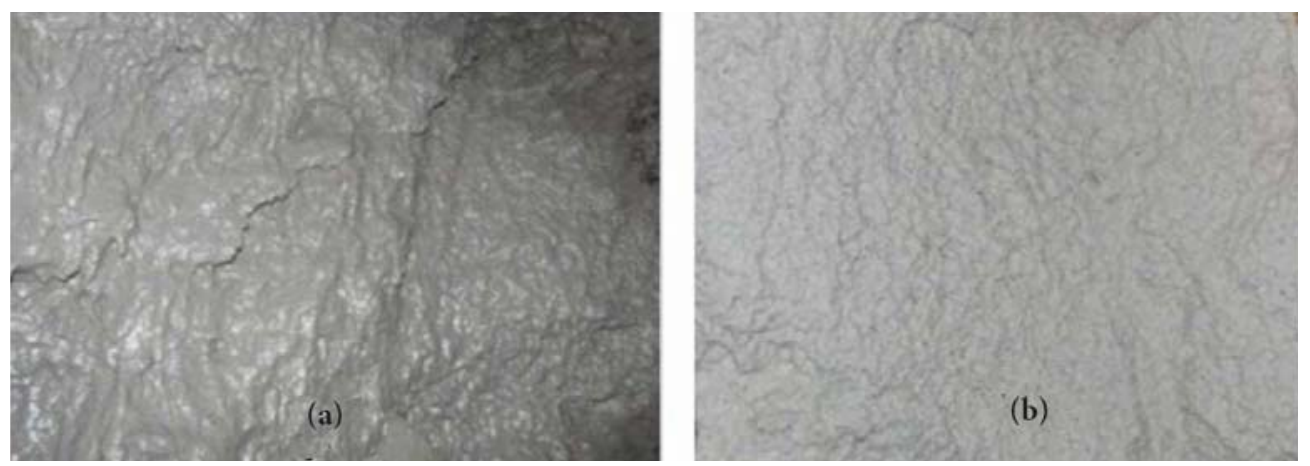

Figure 5-(a) Application of mixture 12; (b) application of mixture 5

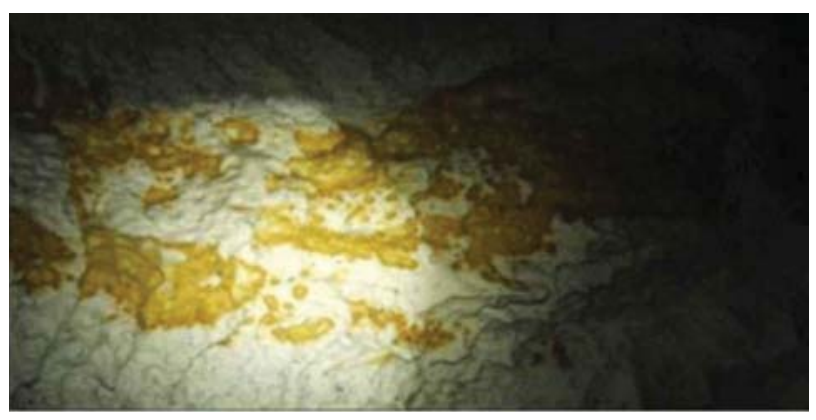

Figure 6-Effect of pyrite on plaster
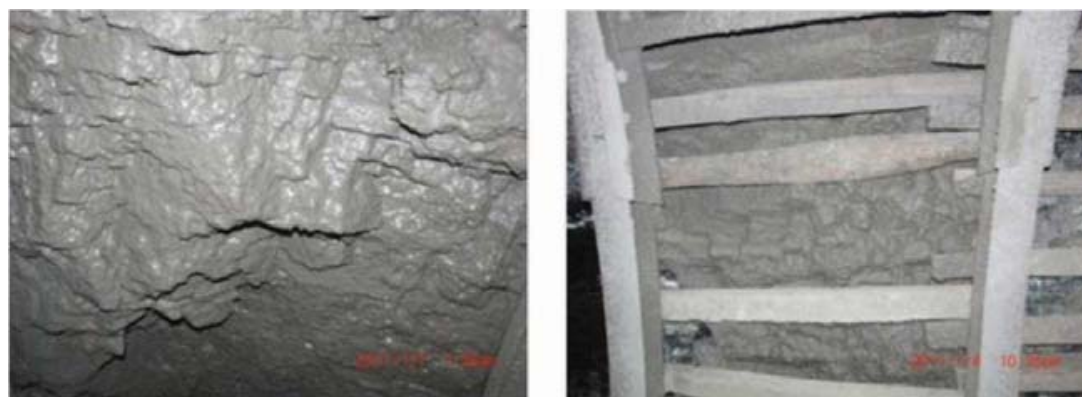

Figure 7-Application of cement, fly ash, and water mixture between two supports 


\section{Prevention of spontaneous combustion in coal drifts using a lining material}

\begin{tabular}{|l|c|}
\hline \multicolumn{2}{|l|}{ Table $V$} \\
Composition of lining material (mixture 12) \\
\hline Material & Vol. \% \\
\hline Fly ash & 75 \\
Portland cement & 25 \\
Water/cement & 2 \\
\hline
\end{tabular}

\begin{tabular}{|ll|ll|}
\hline \multicolumn{4}{|l|}{$\begin{array}{l}\text { Table } \mathrm{VI} \\
\text { Chemical composition of Tuncbilek fly ash (\%) }\end{array}$} \\
\hline $\mathrm{SiO}_{2}$ & 58.25 & $\mathrm{~K}_{2} \mathrm{O}$ & 1.37 \\
$\mathrm{Al}_{2} \mathrm{O}_{3}$ & 16.66 & $\mathrm{Na}_{2} \mathrm{O}$ & 0.33 \\
$\mathrm{Fe}_{2} \mathrm{O}_{3}$ & 12.91 & Ignition loss & 2.09 \\
$\mathrm{~S}+\mathrm{A}+\mathrm{F}$ & 87.82 & $\mathrm{Cl}^{-}$ & 0.002 \\
$\mathrm{CaO}$ & 1.95 & Free $\mathrm{CaO}$ & 0.16 \\
$\mathrm{MgO}$ & 5.08 & Reactive $\mathrm{SiO}_{2}$ & 40.05 \\
$\mathrm{SO}_{3}$ & 0.76 & Reactive $\mathrm{CaO}$ & 1.03 \\
\hline
\end{tabular}

After the laboratory and in-situ studies, the drifts which had a high combustion risk were coated with mixture 12 . The proportions of the mixture used in the pilot studies are given in Table V. An accelerating admixture was added to the mixture at the spray nozzle to lower its rebound. The ratio of accelerating admixture to cement was 0.01 .

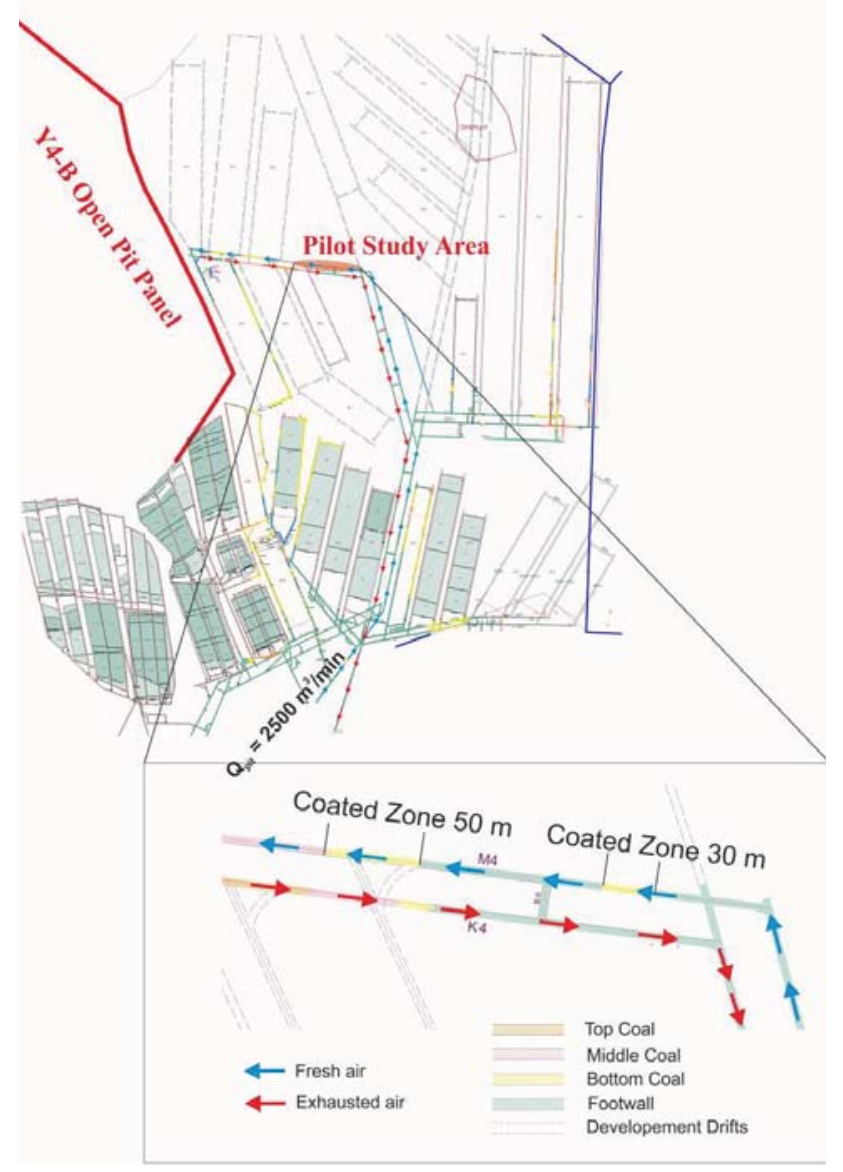

Figure 8-Location of the pilot study

\begin{tabular}{|c|c|}
\hline \multicolumn{2}{|c|}{$\begin{array}{l}\text { Table VII } \\
\text { Technical specifications of spraying machine }\end{array}$} \\
\hline \multicolumn{2}{|l|}{ Specifications } \\
\hline Power & $\mathrm{AC} 380 / 1000 \mathrm{~V} / 50 \mathrm{~Hz}$ \\
\hline Pump motor & $7.5 \mathrm{~kW}$ \\
\hline Mixer motor & $3 \mathrm{~kW}$ \\
\hline Flow rate & $0-120 \mathrm{l} / \mathrm{min}$ \\
\hline Pumping distance (horizontal) & $1000 \mathrm{~m}$ \\
\hline Pumping distance (vertical) & $100 \mathrm{~m}$ \\
\hline Maximum pressure & 40 bar \\
\hline Maximum particle size & $10 \mathrm{~mm}$ \\
\hline Volume of mixer tank & 150 I \\
\hline
\end{tabular}

The fly ash used in this study was supplied from the Tuncbilek power plant. The chemical composition of the fly ash is given in Table VI. Ordinary Portland cement was also used in the mixtures.

A fly-ash silo was established outside the main access to the mine, and a special spray machine was purchased for the pilot study. The spray machine had two tanks: the upper tank was used for mixing dry cement and fly ash, and the lower tank for mixing the blend with water and then pumping it. The technical specifications of the spray machine used in the pilot study are given in Table VII.

The first pilot study was carried out in March 2011. The lining material was applied on the haulage way of panel B, which partly intersected the coal seam (Figure 8). This haulage way was too close to the open pit panels, so the coal around it had a high ignition potential due to air leakage from the cracks connected to the open pit benches. Also, the haulage way was cut by a fault and this increased the ignition potential. The first and second application areas were about 50 and $30 \mathrm{~m}$ in length, respectively.

The wire mesh between the Toussaint-Heintzmann (TH) type supports was ripped out before the spraying process. An $80 \mathrm{~m}$ length of the haulage way of panel B was successfully coated in one shift, and the mesh was replaced after spraying (Figure 9). The behaviour and performance of the lining material was then inspected each month, and no ignition was recorded. After the successful coating application, all new development drifts that were driven into the coal were coated with the cement and fly ash blend immediately after supporting the galleries with TH supports. Since the coating application, no coal fires have been recorded in the Omerler underground coal mine.

The unit cost of the lining material was calculated from the application of the coating between two supports as $\$ 0.42$ per $\mathrm{m}^{2}$ for a $1 \mathrm{~cm}$ thickness, excluding labour. The fire retardant chemical previously used by the mine authorities cost about $\$ 70$ per $\mathrm{m}^{2}$ for a $1 \mathrm{~cm}$ thickness.

\section{Conclusion}

The spontaneous combustion of coal is a serious hazard in underground coal mines. Every year, many underground mineworkers are injured or killed by this kind of disaster, which also causes economic losses for the companies involved.

The easiest way to prevent coal fires is to avoid contact between the coal and air, and an airproof lining material is 


\section{Prevention of spontaneous combustion in coal drifts using a lining material}
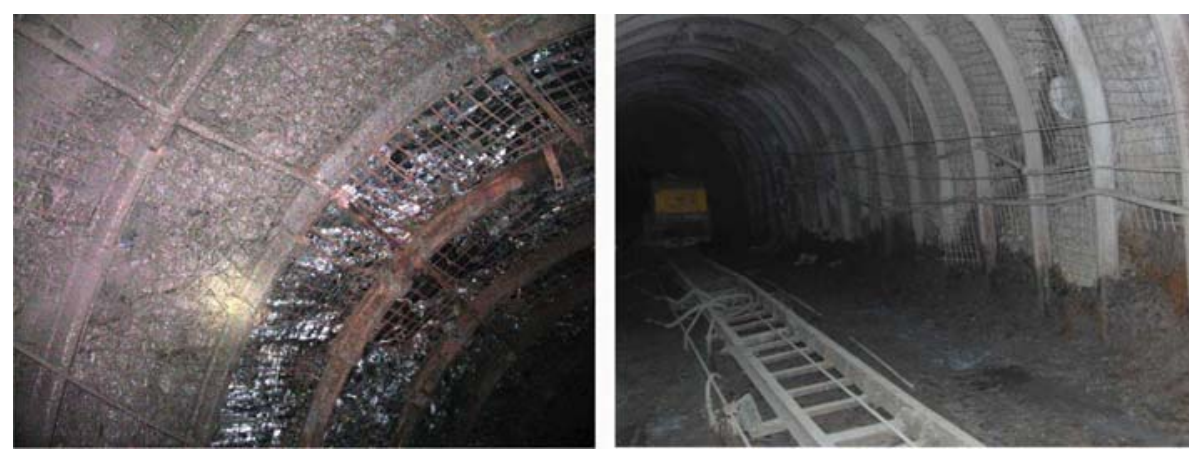

Figure 9-Coated drifts in Omerler underground coal mine

suitable for this purpose. In this study, various airproof lining materials were designed and tested. Given that the first constraint for materials in mixtures is to provide an impermeable barrier to air, the laboratory studies and in-situ applications showed that coating the drifts driven into the coal with a cement plus fly ash and water mixture could prevent coal fires. Furthermore, the cost of materials was shown to be acceptable, as the cement proportion in the mixture was low and the cost of fly ash was almost negligible. However, some procedures have to be considered before and after spraying application.

> The spraying process has to be done before ignition starts

> Large gaps in a drift section have to be filled before the spraying application

> The coating has to be applied between the main supports, just after the main support elements are set up. Then other support elements like wire mesh, wedges, or canopy can be placed between the supports

> The thickness of cement plus fly ash blend has to be a minimum 7-8 mm to provide air impermeability

> To prevent breakage of the lining material, high deformation rates caused by the roof load cannot be tolerated in the drift section

- The coated surfaces must be checked regularly, and failed surfaces must be repaired immediately.

Using this method, coal fires can be prevented effectively and economically.

\section{Acknowledgements}

The authors would like to thank the technical staff of GLI of Turkish Coal Enterprises for their motivation and help in the application of tested materials on drift surfaces. The laboratory studies for this investigation were presented at the 23rd World Mining Congress 2013, Canada (Onur et al., 2013).

\section{References}

CoLAIzZI, G.J. 2004. Prevention, control and/or extinguishment of coal seam fires using cellular grout. International Journal of Coal Geology, vol. 59. pp. $75-81$.

DAvIS, J.D. and ReynoLDS, D.A. 1928. Spontaneous heating of coal. TP 409. US Bureau of Mines. pp. 74.

Gu ANové, P. 2008. Spontaneous combustion of coal and its early detection in Okr mines. GeoScience Engineering, vol. 4. pp. 23-28.

GARP LIGNITE. 2017. http://www.gli.gov.tr/faaliyet.html [accessed 22 November 2016].
GREWER, T. 1994. Thermal Hazards of Chemical Reactions. Elsevier, Amsterdam.

Handa, T., Nishimoto, T., Morita, M., and Komada, J. 1985. Spontaneous combustion of coal. Fire Science and Technology, vol. 5. pp. 21-30.

Jones, R.E. and TownEnd, D.T.A. 1949. Oxidation of coal. Journal of the Society of Chemical Industry, vol. 68. pp. 197.

KАYмАКс̧ı, E. and DiDARI, V. 2000. Relations between coal properties and spontaneous combustion parameters. Turkish Journal of Engineering and Environmental Sciences, vol. 26. pp. 59-64.

KuRAL, O. 1998. Coal Specifications, Technology and Environmental Correlations. Ozgun Printing House, Istanbul.

LI, L., BeAmish, B.B., and JiAng D.Y. 2009. Self-activation theory of spontaneous combustion of coal. Journal of China Coal Society, vol. 34, no. 4. pp. 505508.

Li, Z., SAydam, S., Mitra, R., and Chalmers, D. 2016. Potential use of thin spray-on liners for gas management in underground coal mines. Journal of the Southern African Institute of Mining and Metallurgy, vol. 116. pp. 1091-1100. http://dx.doi.org/10.17159/2411-9717/2016/v116n12a1

LIANG, Y. and WANG, S. 2017. Prediction of coal mine goaf self-heating with fluid dynamics in porous media. Fire Safety Journal, vol. 87. pp. 49-56.

Onur, A.H., Karakus, D., Ozdogan, M.V., KonaK, G., and Yalcin, E. 2013. Design of an optimal lining material to prevent coal fires at underground coal mines. Proceedings of the 23rd World Mining Congress, Montreal, Canada, 11-15 August. CIM, Montreal.

OrEn, O. and Sensogut, C. 2010. Spontaneous combustion liability of Kutahya (Turkey) region lignites. Energy Sources, Part A, vol. 32. pp. 877-885.

Philips, H., Uludač , S., and Chabedi, K. 2011. Prevention and control of spontaneous combustion. Coaltech Research Association, Johannesburg, South Africa.

SARAç, S. and SOYTURK, T. 1992. An investigation on the liability of Tuncbilek lignites to spontaneous combustion. Proceedings of the 8th Coal Congress of Turkey, Zonguldak, 6-8 June 2012. pp. 141-152. https://doi.org/10.1080/15567031003587605

SinGH, R.V.K. 2013. Spontaneous heating and fire in coal mine. Procedia Engineering, vol. 62. pp. 78-90.

Tibbs, M.P., Tyler, O.K., Duin, S.V., and BaAfi, E. 2013. Autonomous thin spray-on liner application in irregular tunnel and mine roadway surfaces. Proceedings of the 30th International Symposium on Automation and Robotics in Construction, Mining \& Petroleum Industries. CIM, Montreal. pp. 1456-1463.

WANG, H., DLugogorski, B.Z., and Kennedy, E.M. 1999. Theoretical analysis of reaction regimes in low-temperature oxidation of coal. Fuel, vol. 78. pp. 1073-1081.

WAng, D., Dou, G., Zhong, X., Xin, H., and QIN, B. 2014. An experimental approach to selecting chemical inhibitors to retard the spontaneous combustion of coal. Fuel, vol. 117. pp. 218-223.

YILDIRIM, O.S., SENSOGUT, C., and GoKAY, M.K. 2006. Effects of electrical resistance on spontaneous combustion tendency of coal and interaction matrix concept. Journal of University of Science and Technology Beijing, vol. 13. pp. 1-7.

ZENG-HUA, L., YA-LI, W., NA, S., Yong-LIANG, Y., and Yu-JING, Y. 2009. Experiment study of model compound oxidation on spontaneous combustion of coal. Procedia Earth and Planetary Science. pp. 123-129.

ZuBíčEK, V. 2008. Assessment of susceptibility of coal to spontaneous combustion in Okr. GeoScience Engineering, vol. 4. pp. 1-9. 